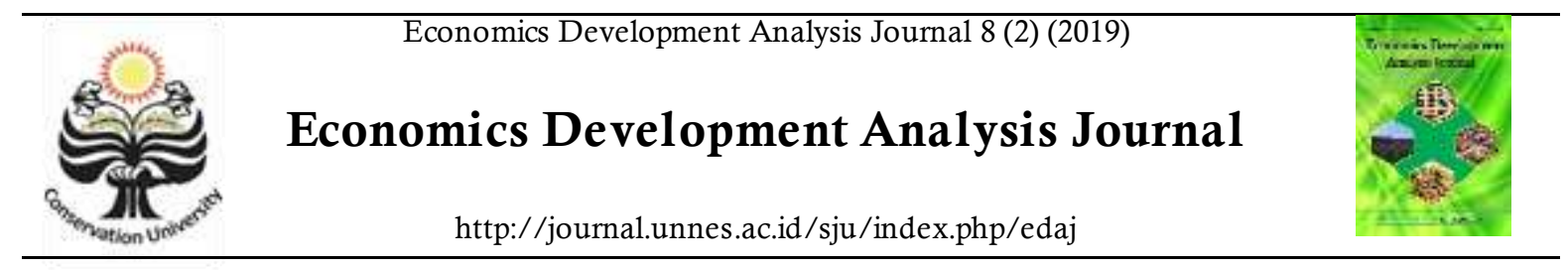

\title{
The Impact of 900VA Electricity Tariff Adjustment on Household Consumption
}

\author{
Nilam Anggar Sari ${ }^{\bowtie},{ }^{2}$ Raudatul Adawiyah
}

Universitas Kutai Kartanegara

\begin{tabular}{ll}
\hline Article Info & Abstract \\
\hline $\begin{array}{l}\text { Hisrtory of Article } \\
\text { Received January 2019 } \\
\text { Accepted March 2019 } \\
\text { Pusblished May 2019 }\end{array}$ & $\begin{array}{l}\text { The aim of this study was to analyze the impact of 900 VA electricity tariff adjustments on household } \\
\text { consumption patterns in East Borneo. This policy potentially increased the poverty, considering that } \\
\text { in this study used the Linear Approximation of Almost Ideal Demand System (LA/ AIDS), and the } \\
\text { concept of elasticity to reach the objectives of this study using Susenas in 2016 and 2017. The results } \\
\text { of the analysis showed that the policy indirectly had more impact on all residential electricity } \\
\text { customers rather than on 900 VA and above customers. The residential electricity customers would } \\
\text { generally be more responsive to reduce the non-staple consumption in addition to respond the } \\
\text { subsidies revocation, compared to 900 VA and above users. This circumstance was certainly related } \\
\text { to the economic condition of 900 VA and above residential electricity customers who were more }\end{array}$ \\
$\begin{array}{l}\text { Keywords: } \\
\text { capable, so the food needs were no longer a household staple. Meanwhile, the middle economic } \\
\text { households would continue to maintain the nutritional status of the household by continuing to } \\
\text { consume high protein food sources (fish / meat / eggs / milk). Meanwhile, based on the type of } \\
\text { Urban, Rural, Household } \\
\text { consumption, Electricity } \\
\text { tariff }\end{array}$ & $\begin{array}{l}\text { region, the revocation of } 900 \text { VA subsidies and the increase in household non-subsidized tariffs for } \\
\text { rural was more responsive than urban households. This was understandable since the level of } \\
\text { electricity dependence of the urban community was quite high than the rural area. }\end{array}$
\end{tabular}

\footnotetext{
${ }^{\mathbb{C}}$ Corresponding author:

Address: Febis Unikarta Jalan Gunung Kombeng no.27

Tenggarong, Kutai Kartanegara, Kalimantan Timur

E-mail: nilamanggarsari@gmail.com
}

ISSN 2252-6560 


\section{INTRODUCTION}

Nowadays, Indonesia is experiencing the growth in electricity consumption which tends to be wasteful and unproductive. This is indicated by the ratio of Gross Domestic Product (GDP) per capita to electricity consumption per capita which is still relatively low. The relationship between GDP per capita with electricity consumption per capita is that Indonesia's position is still below Thailand and Malaysia, and slightly below the average of ASEAN countries, even far behind Brunei Darussalam and Singapore in terms of efficient utilization of electricity (Mulyani \& Hartono, 2018). Thus, as an effort to implement energy efficiency, the government gradually adjusts electricity tariffs. This is the main problem of research in which this policy potentially has consequences for increasing poverty and decreasing welfare in East Borneo province considering that in the last few years this province has experienced negative economic growth. The decline phase occurred since 2014 , which was $1.71 \%$ from the previous $2.25 \%$ in 2013. On the contrary, in 2015, East Borneo experienced a contraction in the rate of economic growth of $-1.2 \%$ and $-0.36 \%$ in 2016 . Therefore, the government needs to be aware of the negative economic impact due to the increase electricity tariffs. The basic electricity tariff is the selling price of electricity applied by State
Electricity Company (PLN) customers imposed by the government. Basic electricity tariffs are also commonly referred to electricity tariffs or electricity power tariffs (TTL). In January 1, 2017, the government through the Ministry of Energy and Mineral Resources (ESDM) and PLN officially revoked electricity subsidies for some groups of 900 VA electricity customers. This policy has been regulated in the Minister of Energy and Mineral Resources Regulation No. 28 of 2016 concerning PT PLN electricity tariffs which regulates the application of non-subsidized tariffs for 900 VA households, and Minister of Energy and Mineral Resources Regulation No. 29 of 2016 concerning the mechanism for providing subsidized TTL for households. The government imposes a tariff adjustment in which the new mechanism that was set adjusts to the cost of electricity supply. It is influenced by fuel prices, the rupiah exchange rate and monthly inflation. This policy was issued in order to make the subsidies right on target.

In fact, the survey results showed that around 18.99 million of 23.09 million of $900 \mathrm{VA}$ electricity customers were not eligible to receive electricity subsidies (economically capable households). This is in line with the data provided by the Integrated Data from Penanganan Program Fakir Miskin which states that only around 4.10 million of 900 VA customers are eligible to be subsidized (Table 1).

Table 1. The Data of Residential Electricity Customers which Received Subsidies in 2016 and 2017

\begin{tabular}{cccc}
\hline Tariff Groups & $\begin{array}{c}\text { Customers } \\
\text { (million) }\end{array}$ & Tariff Groups & $\begin{array}{c}\text { Customers } \\
\text { (million) }\end{array}$ \\
\hline R.1/450VA & 23.16 & R.1/450VA & 23.16 \\
R.1/900VA & 23.09 & R.1/900VA & 4.10 \\
R.1/1300VA & & R.1/900VA-RTM & 19.99 \\
R.1/2200VA & 2.83 & R.1/1300VA & 8.83 \\
R.2/>3500 to 5.500 VA & 0.91 & R.1/2200VA & 2.45 \\
R.3/6600 VA and above & 0.20 & R.2/>3500 to 5.500 VA & 0.91 \\
Total & 58.63 & Total & 0.20 \\
\hline
\end{tabular}

Source: (Ministry of Energy and Mineral Resources, 2017)

For the government, the tariff adjustment is intended to make the funds coming into PLN can be used to improve aspects of electricity distribution in every corner of Indonesia. Nowadays, the electrification ratio of Indonesia has only reached $89.5 \%$. In other words, it is still lagging behind neighboring states such as Singapore, Malaysia, Thailand, and Vietnam which have reached $98 \%$. The subsidies which were considered not on target later will be diverted to seven million households to increase the national electrification ratio. PT PLN data showed that there are 408,650 of 900 VA customers in East Borneo and only 44,756 customers are eligible to receive subsidies. These customers are categorized as poor according to the verification results of the National Team for the Acceleration of Poverty Reduction (TNP2K). TNP2K imposes up to 100 criteria for poverty compared to BPS (Central Bureau of Statistics) which uses only 14 indicators. Therefore, as many as 363,894 900 VA electric customers' 
subsidies have officially been revoked. They are no longer eligible to receive government subsidies, each amounting to Rp 110 thousand per customer. It means that households must pay higher electricity costs than formerly or their spending on electricity will be raised because of bills rising. In fact, the household sector (in terms of expenditure) has a significant contribution in economic growth in the province of East Borneo.

The previous explanation is proved by PDRB Data based on Current Prices which reveals the distribution of household consumption expenditure in 2013 that reached $14.14 \%$ and increased in 2016 until 17.90\% (BPS East Borneo, 2018a). As a result, if there is a change in government policy such as an adjustment (revocation of subsidies) of 900VA electricity tariffs, in case it is assumed a fixed income level, the community must reduce other non-essential costs so as to reduce people's purchasing power. This condition potentially increases poverty. Especially considering that 900 VA electricity customers are a group of people who are nearly on the poverty line and most of them are the informal workers.

Table 2. Depth Index, Poverty Severity Index and Gini Coefficient

\begin{tabular}{cccc}
\hline Year & $\begin{array}{c}\text { Depth } \\
\text { Index of } \\
\text { Poverty }\end{array}$ & $\begin{array}{c}\text { Severity } \\
\text { Index of } \\
\text { Poverty }\end{array}$ & $\begin{array}{c}\text { Gini } \\
\text { Ratio }\end{array}$ \\
\hline 2015 Sept & 0.693 & 0.167 & 0.315 \\
2017 Sept & 0.874 & 0.187 & 0.333 \\
2018 & 0.846 & 0.197 & 0.342 \\
March & & & \\
Source: (BPS of East Borneo, 2017a) &
\end{tabular}

Source: (BPS of East Borneo, 2017a)

Further, the problem of poverty is not only related to the number and percentage of poor people are. However, the most important dimension is related to the depth and severity index of poverty. The poverty depth index in the province of East Borneo which has been increasing in the last few years proves that poverty will be increasingly difficult to alleviate since the expenditure of the poor people is getting further away. Subsequently, the poverty severity index in 2015 increased to 0.197 in 2018 from 0.167 . This rising index showed that the poor people spending is getting unbalanced. This imbalance is also showed by the increasing Gini Ratio of East Borneo province (Table 2).

Based on data household consumption patterns, the majority of population expenditure in East Borneo in 2017 was to meet non-food consumption needs, while the rest was for food consumption. The average expenditure per capita a month in East Borneo Province in 2017 was Rp. 1,443,928, - (BPS of East Borneo, 2017b) in which Rp. 663,535, - was used to meet food consumption and Rp. 780,393, - was for nonfood consumption.

Admittedly, consumption expenditure is one aspect in measuring the level of public welfare. The higher the level of household income, the smaller proportion of expenditure for food to all household expenses will be. In other words, the households will be more prosperous if the percentage of expenditure for food is much smaller than the percentage for non-food (Sari, 2016).

On the other hand BPS data indicates that pre-prosperous families in East Borneo Province have increased in recent years (Table 3). Pre Prosperous family is defined as a family that has not been able to meet the minimum basic needs. Incorrect application of policies will make it increasingly difficult to alleviate them from preprosperous to be prosperous families.

Table 3. The Number of Pre-prosperous Fa milies in East Borneo Province

\begin{tabular}{cc}
\hline Year & Total \\
\hline 2011 & 46,029 \\
2012 & 29,229 \\
2013 & 45,465 \\
2014 & 53,308 \\
2015 & 52,006 \\
2016 & 54,159 \\
2017 & 60,151 \\
\hline \multicolumn{2}{c}{ ource: (BPS of East Borneo, 2018b) }
\end{tabular}

Additionally, studies conducted by (Isdinarmiati, 2011), (Akili, 2014), (Rahmi, 2001), (Sahara, 2003), (Vihara, 2003), and (Komaidi \& Rakhmanto, 2010) noted the negative impact on consumption because of the increasing electricity tariff. Hence, a simulation is urgently needed to see the extent of the impact of government policies on household consumption patterns, especially changes in commodity demand. Above all, the contribution and the novelty of this study compared to previous researches is on the different objects with the special scope of the province, namely East Borneo and the evaluation of policies that have just been implemented per January 1st, 2017 with the LA-AIDS method that has never been done before. The understanding of the impact of the $900 \mathrm{VA}$ power adjustment on 
consumption patterns was expected to be beneficial for policy makers, especially related to poverty alleviation and food security. Based on the previous description, the main objective in this study was to analyze the impact of the 900 VA electricity tariff adjustment policy on household consumption patterns in East Borneo province.

\section{RESEARCH METHODOLOGY}

This study used East Borneo Province as the object with secondary data collected by the Central Statistics Agency, namely consumption module and core data in the National Socioeconomic Survey (Susenas) in March 2016 and 2017 which were cross section data with household sampling units. In March 2016 the number of households as the research sample were 2398 households and in 2017 there were 2864 households. Susenas collected the core data and consumption / expenditure module data and household income. The collected data in the core included information on household members, health, education, housing, and other socioeconomic matters. Meanwhile, the Susenas consumption module contains the quantity and value of food consumption which includes 215 commodities with 14 commodity sub-groups.

The Marshallian Demand Function developed by Marshall mentions that a quantity of consumption or demand for a commodity by a consumer is influenced by the price level of that commodity, the price of other commodities, and income. Consumers were assumed to have a rational nature which was aimed to maximize its utility based on the limits of the amount of income or budget that is owned. They tended to choose various combinations of items with budget constraints. The consumer demand function which was adjusted for budget constraints is written mathematically as follows:

$$
V_{i}=f\left(q_{1} q_{2} \ldots q_{n}\right)+\lambda\left(y-\sum_{i=1}^{n} p_{i} q_{i}\right)
$$

With $y$ is income (constant), $p_{i}$ is the price of the goods to $i, q_{i}$ is the quantity of goods to $i$ , and $\lambda$ is the marginal utility of income. The amount of commodity consumption is not only influenced by economic factors (income and prices), but is also influenced by social characteristics. Differences social characteristics can cause differences in preferences for a commodity that result in differences in consumption patterns. Social characteristics include the level of education of household heads, location of residence, number of household members, and so on. One of approaches to include these socio-economic variables is to make the socioeconomic variable one of the independent variables, which can be stated in the following formula:

$X_{i}=f_{i}\left(P_{i}, Y, S E\right)$

P: Price, Y: Income, and SE: Social Variables. The large influence of socioeconomic characteristics will have an impact on the magnitude of differences in preferences for certain types of commodities. One model to analyze the consumption functions with socioeconomic variables is the Linear Approximation-Almost Ideal Demand System (LA-AIDS) model developed by (Deaton, 1980). The model is presented in the following equation (2).

$$
\begin{array}{r}
W_{i}=\sum_{j \neq i}^{n} \alpha_{j} \log p_{j}+\sum_{j=1}^{n} \gamma_{i j} \log p_{j}+ \\
\beta_{i} \log y-\beta_{i} \sum_{i=1}^{n} w_{i} \log p_{i}
\end{array}
$$

Furthermore, logarithmic functions can be written in the form of natural logarithmic functions. The LA-AIDS model can be restricted or unrestricted, where the restricted model expects several assumptions from the demand function to be met:

\section{Adding Up:}

$\sum_{i=1}^{n} w_{i}=1, \sum_{i=1}^{n} \alpha_{i}=\sum_{i=1}^{n} \gamma_{i j}=0, \sum_{i=1}^{n} \beta_{i}=0$

Homogeneity: $\sum_{j=1}^{n} \gamma_{i j}=0$

Symmetry: $\gamma_{i j}=\gamma_{j i}$

The flexible AIDS cost function results in the demand function equation (2) becomes the first order approximation of consumer behavior in maximizing satisfaction. If the satisfaction is not met or not assumed to occur, the LA-AIDS demand function remains a function related to 
income and prices, so without homogeneity and symmetry restrictions, the function is still the first order approximation of demand function in general.

Moreover, the LA-AIDS model uses a restricted model with the expectation of fulfilling several assumptions of the demand function, such as adding up, homogeneity, and symmetry. Based on reason that the intergroup food is an econometric equation system, this estimation approach is used with Seemingly Unrelated Regression (SUR) through Generalized Least Square (GLS) procedures. The GLS procedure is carried out to increase the efficiency of the allegations and does not require a classic assumption test.

There are two problems in the LA-AIDS demand function model, namely simultaneous bias and selectivity bias. An equation containing simultaneous biases will produce a biased estimator. Simultaneous bias can be overcome by using the instrument price variable as an independent variable that is the unit value that is corrected by the quality of goods purchased (quality effect) and the amount purchased (quantity premium). Variable price corrected instruments are obtained through price deviation regression. Furthermore, one way to overcome selectivity bias is by grouping food commodities (Sari, 2016).

The formation of commodity groups by researchers is usually based on prior research, study needs, local food, food nutrient content, policy objectives, and other considerations. Meanwhile in this study, food groups were formed based on the nutrient content of the commodities analyzed, which were divided into 5 large groups. The grouping included grains / tubers (carbohydrates), fish / meat / eggs / milk (animal protein source), vegetable / fruit (vegetable protein sources, vitamins and minerals), other foods groups consisting of fat / legume commodities, beverage ingredients , spices and cooked foods and the last group was electricity. Further in this study, the LA-AIDS model referred to Deaton and previous studies as follows:

$$
\begin{gathered}
w_{i}=\alpha_{i o} \sum_{j} \gamma_{i j} \log p_{j}+\beta_{i} \log (y / P)+ \\
\alpha_{i 1} \text { Education }+\alpha_{i 2} \text { Health } \\
+\sum_{k} \theta_{i k} \ln S_{k}+\alpha_{i 4} I M R_{i}+u_{i} \ldots \ldots \ldots \ldots .
\end{gathered}
$$

Notes:

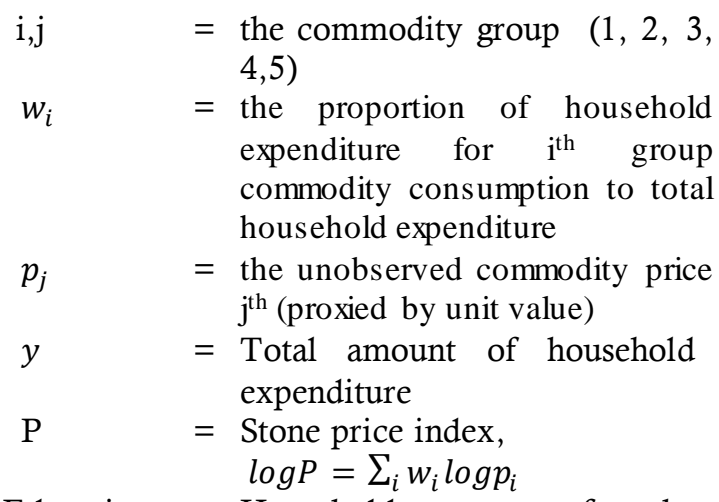 $\mathrm{j}^{\text {th }}$ (proxied by unit value)
$y=$ Total amount of household expenditure
$\mathrm{P}=$ Stone price index, $\log P=\sum_{i} w_{i} \log p_{i}$

Education $=$ Household expenses for the education costs of household members (ART) who attend school

Health = Household expenses for health costs

$S_{k} \quad=$ The $\quad \mathrm{k}^{\text {th }} \quad$ socioeconomic characteristics (expenditure on education costs / EDUCT, health expenses / HEALTH, head of household education / Diploma, employment of head of household / LAPEK, area classification / TYPE, number of household members / ART, proportion of toddler / PROBLT, and the art proportion of school member / PROSEK

$I M R_{i} \quad=$ Inverse Mills Ratio, the Correction variable of the estimated price of the commodity group to i-th consumed by the household

$$
\begin{array}{cc}
\alpha_{\mathrm{i} 0}, \alpha_{\mathrm{i} 1}, & \\
\alpha_{\mathrm{i} 2}, \alpha_{\mathrm{i} 3}, & =\text { Estimated parameters } \\
\alpha_{\mathrm{i4}}, \alpha_{\mathrm{i} 5} \gamma_{\mathrm{ij},} & \\
\beta_{\mathrm{i}} & \\
u_{i} & =\text { Residual (error term) }
\end{array}
$$

This study used descriptive analysis methods and econometrics. The data were processed with the STATA application program package version 13 . The econometric model used was a function model of the LA-AIDS request system. This model was used to reach the research objectives. Meanwhile, responses to changes in household food consumption due to changes in prices and income were reached by using the elasticity value calculated from the estimation coefficient of the model.

The elasticities used in this analysis included income elasticity, own-price elasticity and cross-elasticity. Elasticity was defined as a measure of the percentage change in a variable 
caused by a change in one percent for another variable.

Further, the demand elasticity showed the percentage change in the quantity of goods demanded due to changes in one percent of the variables that affect it, while other conditions were assumed to be unchanged (ceteris paribus). Above all, in this study income was proxied for household expenditure so that the elasticity used was the expenditure elasticity approach. According to (Deaton, 1980), the elasticity is calculated by the following formula:

1. The price elasticity is formulated as follows:

$$
E_{11}=\frac{\partial q_{1}}{\partial p_{1}} \frac{p_{1}}{q_{1}}
$$

The own-price elasticity is the percentage change in the quantity of goods demanded due to changes in the price of the goods. The value of elasticity can distinguish goods into several properties: value $|\varepsilon|<1$ (inelastic goods), $|\varepsilon|$ $=1$ (unit elastic item), and $|\varepsilon|>1$ (elastic item).

2. The cross elasticity is formulated as follows:

$$
E_{21}=\frac{\partial q_{2}}{\partial p_{1}} \frac{p_{1}}{q_{2}}
$$

The cross price elasticity shows the percentage change in the quantity of goods requested due to changes in the prices of other goods. The value of the cross-price elasticity depends on the relationship of two goods in which it has complementary goods with a value of elasticity $<0$, substitute goods (substitution) with an elasticity value $>0$, or there is no useful relationship in the two goods (neutral) unless the value cross price elasticity $=0$.

3. The income elasticity is formulated:

$E_{1 y}=\frac{\partial q_{1}}{\partial y} \frac{y}{q_{1}}$

The income elasticity shows the measurement of the response to consumer demand for a commodity due to changes in consumer income. The value of income elasticity can be used to classify an item whether it is inferior, normal, or luxury. The elasticity value can be divided into: $\varepsilon<0$ (the item includes inferior goods), $0<\varepsilon<1$ (the item includes normal or basic goods) and $\varepsilon>1$ (the item includes luxury goods).

\section{RESULTS AND DISCUSSION}

Electricity Tariff (TTL) is the selling price of electricity applied by the government for the customers of PLN. PLN has subsidized and nonsubsidized customer tariff groups. In 2015 and 2016 there were two groups received subsidies from the government, namely R1 450VA and R1 900 VA groups. Meanwhile, 1300 VA and above groups did not received the subsidies or called as non-subsidized groups. In January 1, 2017 the first subsidy revocation was conducted. It was for the 900 VA group which was divided into 900 VA subsidy and 900 VA non-subsidy.

Table 4. The Electricity Tariff Adjustment of Household for the Period of 2015-2017

\begin{tabular}{lccccc}
\hline Tariffs Groups & Power & March 2015 & March 2016 & January 2017 & $\begin{array}{c}\text { \% TTL Increase } \\
\text { (March 2016- } \\
\text { January 2017 }\end{array}$ \\
\hline R-1/TR & $450 \mathrm{VA}$ & 415.00 & 415.00 & 415.00 & 0.00 \\
$\mathrm{R}-1 / \mathrm{TR}$ & $900 \mathrm{VA}$ & 605.00 & 605.00 & 605.00 & 0.00 \\
$\mathrm{R}-1 / \mathrm{TR}$ & $900 \mathrm{VA}^{*}$ & & & 791,00 & 30.74 \\
$\mathrm{R}-1 / \mathrm{TR}$ & $1.300 \mathrm{VA}$ & $1,352.00$ & $1,355.00$ & $1,467.28$ & 8.29 \\
$\mathrm{R}-1 / \mathrm{TR}$ & $2.200 \mathrm{VA}$ & $1,352.00$ & $1,355.00$ & $1,467.28$ & 8.29 \\
$\mathrm{R}-2 / \mathrm{TR}$ & $3.500-5.500$ & $1,426.58$ & $1,355.00$ & $1,467.28$ & 8.29 \\
$\mathrm{R}-3 / \mathrm{TR}$ & VA & $1,426.58$ & $1,355.00$ & $1,467.28$ & 8.29 \\
\hline
\end{tabular}

Source: PT. PLN

Note: *) 900 VA Non-subsidy 
For non-subsidized customers, PLN applies tariff adjustment mechanism. This policy was valid from January 1, 2015 based on the Minister of Energy and Mineral Resources Regulation no. 31 year 2014. The adjustment is applied every month by considering 3 factors, namely: changes in rupiah exchange rate, fuel prices, and monthly inflation. Through tariff adjustment mechanism, the electricity tariffs would adjust market condition. The weakening of rupiah exchange rate against US dollar in November 2015 and December 2015 inflation, namely from $\mathrm{Rp} 13.673$ to $\mathrm{Rp} 13.855 / \mathrm{US} \$$ or from 0.21 percent to 0.96 percent also contributed to the cause of tariffs adjustment. It even worsened by the drop of Indonesia oil prices from 41.44 US\$ in Novermber 2015, to 35.47 US\$ per barrel.

Through tariff adjustment mechanism, starting from 1 January 2017, the TTL of 900 VA subsidy was set at Rp 791 per VA, while the TTL of 1,300 VA subsidy and above increased to Rp $1,467.28$ per VA. For more, the TTL of 900 VA non-subsidy was slowly adjusted to be closer to other non-subsidized tariff groups, namely $\mathrm{Rp}$ 1,304 per VA. In this study, the impacts of subsidy revocation policies on some $900 \mathrm{VA}$ electricity customers were identified in accordance with the impact before and after the policies were applied. The impact of TTL before the policies were applied was displayed using a model containing 2016 data, while the impact after the application of the policies used a model containing 2017 data.

Moreover, LA/ AIDS models used in the analysis of this study were divided into two models. The first model was a model which used all observation units of residential electricity customers. The second model was a model whose observation units were $900 \mathrm{VA}$ and 900 VA and above residential electricity customers. The first model was aimed at seeing indirect impacts of subsidy revocation for 900 VA electricity customers, and non-subsidized TTL increase on all residential electricity customers. Meanwhile, the second model was aimed at seeing direct impacts on the residents with revoked subsidy or the residents whose TTL increased.

There are many approaches can be used to estimate LA-AIDS demand function model. They were such as OLS $<2$ SLS, GLS, and Seemingly Unrelated Regression (SUR). Each estimation has strengths and weaknesses. By considering each food group has a strong relationship one another, and the ease of no classical assumption test, so this study used SUR estimation approach. SUR consists of a set of equations in which each endogenous variable is interconnected with each other because of the correlation between residuals for each group of equations. SUR method uses GLS procedures and can improve prediction efficiency by explicitly considering that there is a residual correlation.

GLS procedures (Generalized Least Square) is used in a case when OLS classical assumption such as homoscedasticity (constant variance) and non-autocorrelation (uncorrelated residual) are not met, so there is no need for classical assumption test. The whole test on SUR model uses Chi-Square test $(\chi 2)$. From the output (Table 5, Table 6, Table 7, Table 8) it can be seen that the P values in both 2016 and 2017 were all less than $\alpha=0.05$, so it could be concluded that the null hypothesis was rejected. It meant that in all commodity groups, both in 2016 and 2017, the variables of food price groups and electricity tariff (PredLnP1, PredLnP2, PredLnP3, PredLnP4, PredLnP5), real household expenditure (LnYriil), health expenditure (LnHealth) ), education expenditure (LnEduct), highest education of household head (IJASAH), type of region (TYPE), employment of head of household (LAPEK), number of household members (LNART), proportion of children under five (PROBLT), and proportion of household members who go to school (PROSEK) simultaneously affected the budget share (W).

Partial test ( $t$ test): the independent variables in commodity groups, both in 2016 and 2017 mostly had a significant influence (marked*). 
Nilam Anggar Sari \& Raudatul Adawiyah / Economics Development Analysis Journal 8 (2) (2019)

Table 5. LA-AIDS Model for All Household Electricity Customers in 2016

\begin{tabular}{llllll}
\hline Variable & \multicolumn{1}{c}{$\mathrm{W} 1$} & $\mathrm{~W} 2$ & $\mathrm{~W} 3$ & $\mathrm{~W} 4$ & $\mathrm{~W} 5$ \\
\hline PredLnP1 & $0.083867^{* * *}$ & $-0.094119^{* * *}$ & $0.012425^{* *}$ & 0.000231 & -0.002405 \\
PredLnP2 & $-0.094119^{* * *}$ & $0.052153^{* * *}$ & $-0.039622^{* * *}$ & $0.022147^{*}$ & $0.059440^{* * *}$ \\
PredLnP3 & $0.012425^{* *}$ & $-0.039622^{* * *}$ & $0.014931^{* *}$ & 0.003381 & $0.008884^{* * *}$ \\
PredLnP4 & 0.000231 & $0.022147^{*}$ & 0.003381 & 0.018054 & $-0.043814^{* * *}$ \\
PredLnP5 & -0.002405 & $0.059440^{* * *}$ & $0.008884^{* * *}$ & $-0.043814^{* * *}$ & $-0.022105^{* * *}$ \\
LnYriil & $0.012812^{* * *}$ & $-0.009657^{* * *}$ & $0.011595^{* * *}$ & $-0.014750^{* * *}$ & $-0.048761^{* * *}$ \\
LnHealth & $-0.002378^{* * *}$ & $-0.001953^{* *}$ & $-0.001170^{* *}$ & -0.001492 & $0.006993^{* * *}$ \\
LnEduct & $-0.006139^{* * *}$ & $-0.003520^{* *}$ & $-0.003332^{* * *}$ & 0.001594 & $0.011396^{* * *}$ \\
IJASAH & 0.001124 & $-0.005624^{* *}$ & -0.001254 & $-0.005942^{*}$ & $0.011696^{* * *}$ \\
TIPE & $-0.006584^{* * *}$ & -0.002055 & $-0.003073^{*}$ & $0.006659^{*}$ & $0.005053^{* *}$ \\
LAPEK & $0.011836^{* * *}$ & -0.000770 & $0.005079^{* * *}$ & $-0.008827^{* *}$ & $-0.007317^{* * *}$ \\
& & & & & \\
LNART & $0.021961^{* * *}$ & $-0.012923^{* * *}$ & $-0.023690^{* * *}$ & 0.000915 & $0.013736^{* * *}$ \\
PROBLT & $0.065988^{* * *}$ & $0.033578^{* *}$ & $0.041476^{* * *}$ & $-0.033530^{*}$ & $-0.107512^{* * *}$ \\
PROSEK & $-0.021696^{* * *}$ & -0.001548 & $-0.018350^{* * *}$ & $0.048657^{* * *}$ & -0.007063 \\
_cons & $0.075171^{* * *}$ & $0.412339^{* * *}$ & $0.076597^{* * *}$ & $0.207713^{* * *}$ & $0.228180^{* * *}$ \\
\hline R2 & 0.3042 & 0.0993 & -0.3663 & 0.1933 & -52.161 \\
Chi2 & 1758.97 & 1032.06 & 702.37 & 343.94 & 261650.77 \\
P & 00.00 & 00.00 & 00.00 & 00.00 & 00.00 \\
\hline legend:* p<0.05;**p<0.01;*** $\mathrm{p}<0.001$ & & & \\
\hline
\end{tabular}

Source: STATA 13 Data

Table 6. LA-AIDS Model for All Household Electricity Customers in 2017

\begin{tabular}{llllll}
\hline Variable & W1 & W2 & W3 & W4 & W5 \\
\hline PredLnP1 & $0.115810^{* * *}$ & $-0.075455^{* * *}$ & -0.006279 & -0.014210 & $-0.019865^{* * *}$ \\
PredLnP2 & $-0.075455^{* * *}$ & $0.035303^{* * *}$ & $-0.039188^{* * *}$ & 0.003584 & $0.075756^{* * *}$ \\
PredLnP3 & -0.006279 & $-0.039188^{* * *}$ & $-0.009054^{*}$ & $0.055230^{* * *}$ & -0.000708 \\
PredLnP4 & -0.014210 & 0.003584 & $0.055230^{* * *}$ & -0.017381 & $-0.027223^{* * *}$ \\
PredLnP5 & $-0.019865^{* * *}$ & $0.075756^{* * *}$ & -0.000708 & $-0.027223^{* * *}$ & $-0.027960^{* * *}$ \\
LnYriil & $0.013254^{* * *}$ & $-0.006283^{* * *}$ & $0.009131^{* * *}$ & $-0.016101^{* * *}$ & $-0.046361^{* * *}$ \\
LnHealth & $-0.002211^{* * *}$ & -0.000407 & $-0.001459^{* * *}$ & $-0.001780^{*}$ & $0.005858^{* * *}$ \\
LnEduct & $-0.004253^{* * *}$ & $-0.002779^{* *}$ & $-0.002062^{* * *}$ & -0.000693 & $0.009787^{* * *}$ \\
IJASAH & -0.000279 & 0.003561 & $-0.003880^{* *}$ & -0.003185 & $0.003783^{*}$ \\
TIPE & $-0.012077^{* * *}$ & $-0.009597^{* * *}$ & $-0.005368^{* * *}$ & $0.009088^{* * *}$ & $0.017953^{* * *}$ \\
LAPEK & $0.009464^{* * *}$ & $0.008320^{* * *}$ & $0.006835^{* * *}$ & $-0.012585^{* * *}$ & $-0.012035^{* * *}$ \\
LNART & $0.019394^{* * *}$ & $-0.015858^{* * *}$ & $-0.014494^{* * *}$ & 0.003310 & $0.007647^{* *}$ \\
PROBLT & $0.068693^{* * *}$ & $0.058092^{* * *}$ & $0.060351^{* * *}$ & $-0.054415^{* *}$ & $-0.132721^{* * *}$ \\
PROSEK & -0.003390 & 0.010186 & 0.005805 & 0.007848 & $-0.020448^{* * *}$ \\
_cons & -0.013186 & $0.412376^{* * *}$ & $0.085756^{* * *}$ & $0.306666^{* * *}$ & $0.208388^{* * *}$ \\
\hline R2 & 0.1570 & 0.1135 & -0.3129 & 0.2387 & -61.423 \\
Chi2 & 1923.45 & 825.25 & 547.21 & 502.56 & 221779.78 \\
P & 00.00 & 00.00 & 00.00 & 00.00 & 00.00 \\
\hline
\end{tabular}

legend: ${ }^{*} \mathrm{p}<0.05 ;{ }^{* *} \mathrm{p}<0.01 ;{ }^{* *} \mathrm{p}<0.001$ 
Nilam Anggar Sari \& Raudatul Adawiyah / Economics Development Analysis Journal 8 (2) (2019)

Table 7. LA-AIDS Model for $900 \mathrm{VA}$ and Above Electricity Customers in 2016

\begin{tabular}{llllll}
\hline Variable & W1 & W2 & W3 & W4 & W5 \\
\hline PredLnP1 & $0.099483^{* * *}$ & $-0.120623^{* * *}$ & $0.013212^{* *}$ & 0.006600 & 0.001328 \\
PredLnP2 & $-0.120623^{* * *}$ & $0.089697^{* * *}$ & $-0.038628^{* * *}$ & $0.021232^{*}$ & $0.048323^{* * *}$ \\
PredLnP3 & $0.013212^{* *}$ & $-0.038628^{* * *}$ & $0.012563^{*}$ & 0.000067 & $0.012786^{* * *}$ \\
PredLnP4 & 0.006600 & $0.021232^{*}$ & 0.000067 & 0.003636 & $-0.031535^{* * *}$ \\
PredLnP5 & 0.001328 & $0.048323^{* * *}$ & $0.012786^{* * *}$ & $-0.031535^{* * *}$ & $-0.030902^{* * *}$ \\
LnYriil & $0.015019^{* * *}$ & $-0.011659^{* * *}$ & $0.011848^{* * *}$ & $-0.015208^{* * *}$ & $-0.048712^{* * *}$ \\
LnHealth & $-0.002122^{* * *}$ & $-0.002041^{*}$ & $-0.001006^{*}$ & $-0.002023^{*}$ & $0.007192^{* * *}$ \\
LnEduct & $-0.002887^{* * *}$ & $-0.007867^{* * *}$ & $-0.003101^{* * *}$ & 0.001632 & $0.012223^{* * *}$ \\
IJASAH & 0.001979 & $-0.006696^{* *}$ & -0.001378 & $-0.006511^{*}$ & $0.012607^{* * *}$ \\
TIPE & $-0.007859^{* * *}$ & $-0.005421^{*}$ & $-0.003550^{*}$ & $0.011449^{* * *}$ & $0.005380^{*}$ \\
LAPEK & $0.015175^{* * *}$ & -0.000083 & $0.005738^{* * *}$ & $-0.012717^{* * *}$ & $-0.008112^{* *}$ \\
LNART & $0.016082^{* * *}$ & $-0.010415^{*}$ & $-0.025954^{* * *}$ & 0.001395 & $0.018892^{* * *}$ \\
PROBLT & $0.097242^{* * *}$ & -0.010989 & $0.044285^{* * *}$ & -0.025753 & $-0.104784^{* * *}$ \\
PROSEK & $-0.024834^{* * *}$ & 0.014050 & -0.009759 & $0.044161^{* * *}$ & $-0.023618^{* *}$ \\
\multicolumn{1}{c}{ cons } & $0.055833^{* * *}$ & $0.410903^{* * *}$ & $0.075548^{* * *}$ & $0.244578^{* * *}$ & $0.213138^{* * *}$ \\
\hline R2 & 0.3213 & 0.1103 & -0.3908 & 0.2249 & -49.189 \\
Chi2 & 1751.50 & 890.43 & 611.72 & 302.07 & 205777.58 \\
P & 00.00 & 00.00 & 00.00 & 00.00 & 00.00 \\
\hline
\end{tabular}

legend: * $\mathrm{p}<0.05 ;{ }^{* *} \mathrm{p}<0.01 ;{ }^{* * *} \mathrm{p}<0.001$

Table 8. LA-AIDS Model for $900 \mathrm{VA}$ and Above Electricity Customers in 2017

\begin{tabular}{|c|c|c|c|c|c|}
\hline Variable & W1 & W2 & W3 & W4 & W5 \\
\hline PredLnP1 & $0.118017^{* * *}$ & $-0.080410^{* * *}$ & 0.001737 & -0.016851 & $-0.022493^{* * *}$ \\
\hline PredLnP2 & $-0.080410 * * *$ & $0.026197 * *$ & $-0.047559 * * *$ & 0.019753 & $0.082019 * * *$ \\
\hline PredLnP3 & 0.001737 & $-0.047559 * * *$ & $-0.010976^{*}$ & $0.063328 * * *$ & -0.006530 \\
\hline PredLnP4 & -0.016851 & 0.019753 & $0.063328 * * *$ & -0.047065 & $-0.019166^{*}$ \\
\hline PredLnP5 & $-0.022493 * * *$ & $0.082019 * * *$ & -0.006530 & $-0.019166^{*}$ & $-0.033829 * * *$ \\
\hline LnYriil & $0.013681^{* * *}$ & $-0.005615^{* * *}$ & $0.009579 * * *$ & $-0.017645^{* * *}$ & $-0.046654^{* * *}$ \\
\hline LnHealth & $-0.002544^{* * *}$ & -0.000437 & $-0.001617^{* * *}$ & -0.001668 & $0.006267 * * *$ \\
\hline LnEduct & $-0.003553^{* * *}$ & $-0.003990 * * *$ & $-0.002236^{* * *}$ & -0.000794 & $0.010573^{* * *}$ \\
\hline IJASAH & 0.001871 & 0.002205 & $-0.003046^{*}$ & -0.001956 & 0.000926 \\
\hline TIPE & $-0.012649 * * *$ & $-0.010736^{* * *}$ & $-0.006048 * * *$ & $0.011504^{* * *}$ & $0.017928 * * *$ \\
\hline LAPEK & $0.007071^{* * *}$ & $0.005767^{*}$ & $0.005879 * * *$ & $-0.010197 * *$ & $-0.008520 * * *$ \\
\hline LNART & $0.016533^{* * *}$ & -0.008164 & $-0.011810 * * *$ & -0.000582 & 0.004024 \\
\hline PROBLT & $0.082728 * * *$ & $0.073288^{* * *}$ & $0.081099 * * *$ & $-0.074814^{* * *}$ & $-0.162300 * * *$ \\
\hline PROSEK & $-0.014698 * * *$ & $0.018396^{*}$ & 0.000026 & 0.010338 & $-0.014061^{*}$ \\
\hline _cons & -0.025453 & $0.438141^{* * *}$ & $0.078904^{* * *}$ & $0.311281^{* * *}$ & $0.197128^{* * *}$ \\
\hline R2 & 0.0672 & 0.1133 & -0.3645 & 0.2713 & -54.756 \\
\hline Chi2 & 1360.47 & 577.52 & 467.29 & 375.63 & 159925.48 \\
\hline $\mathrm{P}$ & 00.00 & 00.00 & 00.00 & 00.00 & 00.00 \\
\hline
\end{tabular}

Source: STATA 13 Data Processing, 2018 
The total of household real expenditure (LnYriil) totally had significant influence on budget share. In addition, almost all food prices had significant influence on their budget share. However, the coefficient values on LA-AIDS model are not easy to interpret. The values would be more valuable when being interpreted in elasticity indicator. The coefficient sign indicates the direction of the relationship of the influence of the independent variable on the dependent variable. The direction of this relationship will be more easily interpreted in elasticity. In this study, the impacts of subsidy revocation policies on several 900 VA customers and the increase of TTL were seen from the condition before and after the policies were implemented. The impacts were showed by changes in price elasticity/ TTL before and after the policies were implemented.
The price elasticity value can be seen in Table 9. The researchers distinguished the price elasticity into two categories based on the level of electricity dependence, namely urban and rural area.

It was made by considering people in urban area depend more on electricity than those in rural area. Further, Table 9 showed that the price elasticity before and after the subsidy revocation / TTL increase was negative. It meant that if TTL increases, household or residents would respond it by reducing electricity usage. It is in line with the theory of consumer demand that there is an inverse relationship between the price and the amount requested, meaning that if the price of a commodity increases, the demand for the commodity will decrease.

Table 9. The Elasticity of Electricity Tariffs before and after Electricity Tariffs Adjustment for 900 VA in January 2017 by Area Types and Electricity Customers

\begin{tabular}{llllc}
\hline \multirow{2}{*}{ Types of Area } & \multicolumn{2}{l}{ All Electricity Customers } & \multicolumn{2}{c}{$900 \mathrm{VA}$ and above Electricity } \\
& Before & After & Before & After \\
\hline Urban & -1.9364 & -1.5762 & -1.9680 & -0.6503 \\
Rural & -1.4404 & -2.1824 & -1.7537 & -1.7638 \\
Total & -1.6277 & -1.8704 & -1.8517 & -1.2626 \\
\hline
\end{tabular}

Source: Susenas, March 2016-2017 (Processed)

Based on table 9, it was known that the value of price elasticity before and after subsidy revocation/ TTL increase has increased, namely from -1.6277 to -1.8704 or it can be said that all residential electricity customers were more responsive in responding 900 VA subsidy revocation and changes in non-subsidized TTL (1,300 VA and above) compared to before the implementation of the policies. The elasticity value of -1.6277 meant that when TTL increases 1 percent, the community would respond it by reducing their electricity usage of 1.6277 percent. Meanwhile, the subsidy revocation/ nonsubsidized TTL increase caused household be more reactive than before, namely in 1 percent TTL increase, households would respond by reducing electricity usage by 1.8704 percent. On the other hand, the elasticity value produced by
LA/ AIDS model showed that the groups of 900 VA and above customers were economically capable, not too responsive to the subsidy revocation or non-subsidized TTL increase. It was understandable since electricity has become the part of their household life needs.

As long as the tariff is affordable, they would still pay it. One thing to note was that the $900 \mathrm{VA}$ and above customers were more resistant to TTL changes than common people. Some of 900 VA electricity customers who were economically capable were more resilient in dealing with TTL changes. It was proved from the values of elasticity before and after the revocation/ TTL increase, namely -1.8571 to 1.2626. These data showed that even though there was an increase in TTL in 2017, the economically capable households were not as 
responsive as the condition before the policies were implemented.

Based on the area categorization, the revocation of electricity and TTL increase in rural areas were more responsive when compared to those in urban areas, both for the common residential electricity customers, and 900 VA or above residential electricity customers. This phenomenon was understandable because the level of electricity dependence of the urban community is quite high compared to that in the village. The urban community seems inseparable from electronic equipment to do various things, such as as a means of lighting, air conditioning, entertainment, cooking fuel, and others. Meanwhile, TTL increase occurred in rural area was spontaneously responded by reducing the electricity usage as an effort to reduce electronic equipment. Reducing electricity usage in rural areas are not complicated because of the abundant stock of cooking fuels and possible environmental condition.

Similar to own-price elasticity, cross price elasticity was also divided using types of area for both common electricity customers, and 900 VA and above customers. The data of this price elasticity are presented in Table 10 . Both positive and negative values of cross price elasticity described 2 kinds of relations between commodity groups. It is positive when there is a substitution relation, while the negative one shows a complementary relation.

Table 10. The Cross-Price Elasticity of Electricity Tariffs before and after 900 VA Electricity Tariffs Adjustment against Demand for Several Commodity Groups by Groups of Electric Customers and Area Types in January 2017

\begin{tabular}{|c|c|c|c|c|c|c|}
\hline \multirow{2}{*}{ Groups of Foods } & \multicolumn{3}{|l|}{ Before } & \multicolumn{3}{|l|}{ After } \\
\hline & K & $\mathrm{D}$ & $\mathrm{K}+\mathrm{D}$ & $\mathrm{K}$ & $\mathrm{D}$ & $\mathrm{K}+\mathrm{D}$ \\
\hline \multicolumn{7}{|l|}{ All Electricity Customers } \\
\hline Grains/ Tubers & 0.7209 & 0.0111 & 0.1593 & 1.5019 & 0.3939 & 0.7627 \\
\hline Fish/Meat/Egg/Milk & -0.8968 & -0.3270 & -0.5126 & -1.0210 & -0.0271 & -0.6852 \\
\hline Vegetable/Fruit & -0.8970 & -0.5395 & -0.7691 & -1.2059 & -1.0596 & -1.1430 \\
\hline $\begin{array}{l}\text { Others } \\
900 \text { VA and Above Electricity } \\
\text { Customers }\end{array}$ & -0.9998 & -0.8125 & -0.8797 & -1.0627 & -0.8672 & -1.0652 \\
\hline Grains/ Tubers & 0.9285 & 0.1086 & 0.3976 & 2.0027 & 1.2167 & 1.7633 \\
\hline Fish/Meat/Egg/Milk & -0.1791 & -0.2822 & -0.1728 & -0.4230 & 0.2315 & $-0,1223$ \\
\hline Vegetable/Fruit & -0.9127 & -0.5818 & -0.8044 & -1.1751 & -1.0122 & -1.1269 \\
\hline Others & -0.8866 & -1.2935 & -0.9634 & -1.4709 & -0.7243 & -0.9987 \\
\hline
\end{tabular}

Source: Susenas, March 2016-2017 (Processed)

Notes: K: Urban, D: Rural

Table 10 showed that the elasticity of electricity tariffs on fish/ meat/ egg/ milk, and vegetable/ fruit group, and other food groups had negative mark, while grains/ tubers group gained positive mark both in urban, and rural area. It was understandable because grins/ tuber group consisted of a group of staples, so an increase in TTL did not make households sacrifice (reduce) its consumption, but they would prefer to reduce consumption on other needs than on the group of staples.
The consumption of staple foods will keep increasing since there was an increasing population and energy needed. Thus, households responded the increase and revocation by consuming grins/ tubers whose responsibility level of 0.7627 . It meant that whenever there is 1 percent of TTL increase, the consumption of grins/ tubers will also increase of 0.76 percent. Meanwhile, the $900 \mathrm{VA}$ and above residential electricity customers had higher responsibility level, namely 1.7633 . 
Nilam Anggar Sari \& Raudatul Adawiyah / Economics Development Analysis Journal 8 (2) (2019)

Table 11. Changes in Responsibility for the Adjustment of the 900 VA Electricity Tariffs in January 2017 Against Non-Staple Food Consumption (percent)

\begin{tabular}{lccc}
\hline Groups of Food & Urban & Rural & Urban+Rural \\
\hline All Electricity Customers & & & \\
Grains/ Tubers & 13.85 & -91.71 & 33.67 \\
Fish/Meat/Egg/Milk & 34.44 & 96.40 & 48.62 \\
Vegetable/Fruit & 6.29 & 6.73 & 21.09 \\
900 VA and Above Electricity & & & \\
Customers & & -17.97 & -29.22 \\
Fish/Meat/Egg/Milk & 136.18 & 73.98 & 40.09 \\
Vegetable/Fruit & 28.75 & -44.00 & 3.66 \\
3. Others & 65.90 & & \\
\hline
\end{tabular}

Source: Susenas, March 2016-2017 (Processed)

Table 11 showed that the electricity customers commonly tended to be responsive in reducing food consumption outside the staple food in dealing with subsidy revocation or TTL increase compared to $900 \mathrm{VA}$ and above residential electricity customers.

If subsidy was revoked or TTL was increased, the household consumption on vegetable/ fruit would increase 48.62 percent, while for those who used $900 \mathrm{VA}$ and above would increase 40.09 percent. For more, the common household responsibility on other food groups' consumption generally would increase 21.09 percent, while for those who subscribed to 900 VA and above would increase 3.66 percent only. Further, the common household responsibility on the consumption of fish/ meat/ egg/ milk would increase 33.67, while the consumption of household which used 900 VA and above decreased 29.22 percent.

These phenomena were surely related to the economic condition of the $900 \mathrm{VA}$ and above customers who were economically more stable, so the need of food was no longer considered as a household staple. Meanwhile, the middle economic household would continue to maintain nutrition by continuing to consume high protein sources (fish/ meat/ egg/ milk), although there was expense of other foods consumption.

Table 12. Expenditure Elasticity before and after Electricity Tariffs Adjustment on the Demand of Several Commodity Groups by Types of Region

\begin{tabular}{lllllll}
\hline Groups of Food & Before & \multicolumn{5}{c}{ After } \\
& $\mathrm{K}$ & $\mathrm{D}$ & $\mathrm{K}+\mathrm{D}$ & $\mathrm{K}$ & $\mathrm{D}$ & $\mathrm{K}+\mathrm{D}$ \\
\hline 1. Grains/Tubers & 1.3377 & 1.1094 & 1.2133 & 1.3239 & 1.1944 & 1.2554 \\
2. Fish/Meat/Egg/Milk & 0.9007 & 0.8790 & 0.8940 & 0.9095 & 0.8635 & 0.8962 \\
3. Vegetable/Fruit & 1.1905 & 1.1927 & 1.1956 & 1.1741 & 1.1165 & 1.1467 \\
4. Others & 0.8862 & 0.9468 & 0.9105 & 0.9130 & 0.9682 & 0.9337 \\
\hline
\end{tabular}

Source: Susenas, March 2016-2017 (Processed)

Notes: K: Urban, D: Rural 
In relation to income elasticity, the analysis in this study compared the proxy of income and the proxy of expenditure, so the elasticity of income was analyzed using the proxy expenditure elasticity. The values of income elasticity can be seen in Table 12. In income elasticity, items were categorized into 2 , namely inferior and normal. It was called inferior if the income elasticity of the items $<0$ and if $\geq 0$, then the items were included in the category of normal. Whereas, normal items were divided into basic items (necessities) and luxurious. It belonged to staple category if the elasticity value was $0-1$, while the luxury category had the value of $>1$.

Based on Table 12, it was known that all income elasticities were positive. It implied there was no groups of food categorized as inferior. In other words, all groups of food were normal items either before or after the provision of subsidy to 900 VA customers and TTL increase on non-subsidized customer. Positive value means if the income increases, the number of demand also increases. Generally, the elasticity values of grins/ tubers group and vegetables/fruits gained value more than 1 , meaning that those groups of commodity were considered as luxurious items for most of East Borneo people. Meanwhile, the group of fish/ meat/ egg/ milk and other foods were categorized as necessities. For East Borneo people, fish/meat/ egg/ milk may be considered as staple since it is inevitably inseparable part of menu (obligatory menu). Moreover, the group of grins/ tubers gained the highest elasticity value compared to others.

Generally the impact of subsidy revocation policies for some of 900 VA electricity customers and TTL increase for non-subsidized residential customers who used $900 \mathrm{VA}$ and above did not significantly influence the behavior of allocating income on food consumption, although there were a bit of elasticity changes after the implementation of the policies (insignificant). Also, table 12 showed that the elasticity of income on the groups of grins/ tubers, fish/ meat/ egg/ milk, and other foods increased after the implementation of the policies, while the group of vegetables/ fruits tended to decrease. The highest increase was experienced by the group of grins/ tubers that turned into 1.2554, meaning that the subsidy revocation for some of 900 VA customers and non-subsidized TTL increase changed the behaviors of households in allocating their income. If household income rises by 1 percent, it would be responded by an increase in consumption of grains / tubers by 1.2554 percent. The next highest increase in income elasticity was the other food groups to 0.9337 and followed by the fish / meat / eggs / milk group to 0.8962 . Meanwhile, the vegetables / fruits group dropped to 1.1467 .

The findings of this study are in line with (Rahmi, 2001) who analyzed the impact of price changes in West Java in which all own-price elasticity was marked negative. It is in accordance with consumers demand theory that there is an opposite relationship between ownprice and the quantity of the demanded goods. It means that whenever the commodity price increases, the demand for the commodity would decrease. Whereas, most of own-price elasticity gained value more than 1 or can be said elastic, meaning that price changes are lower than demand changes. Price elasticity is basically a household response in consuming items by the time there is an increase in the item price. Generally, the study findings also indicated the own-price elasticity of urban households in both model was lower than the rural households. Besides the high dependence of urban household on electricity, the level of income earned by the urban household was relatively high compared to those in rural area, so the urban household had a higher purchasing power than rural households.

The results of this study were based on the cross variance elasticity value, both negative and positive. They were also in lien with Kahar's study (2010). This study was conducted in Banten by simulating price increase that resulted in the domination of negative cross elasticity value. The negative elasticity value made the group of foods considered as complementary items. Complementary item means whenever there is an increase in price, there will be a 
decrease in demand, and vice versa. Meanwhile, there was only a small portion of food groups having positive value, meaning that the items still belonged to substitution category. One form of complements that occurred was the relationship between grains/ tubers with education. The relationship meant that the increase in grins/ tuber prices caused the decrease in education consumption demand, and vice versa. It showed that the society still prioritized staple foods to meet their daily needs. In this study, TTL increase did not cause the households to reduce staple foods consumption. However, they tended to reduce other items consumption other than staple foods. It proved that staple foods consumption would remain increasing as the population and energy increase.

The results of this study are also in line with Sari's study, 2016 that the expenditure elasticity value in this study gained positive values. Based on a theory, positive value indicated that all food groups belonged to normal items or not inferior. Positive mark also meant that whenever the income allocated for foods increase, the demand of the particular foods would also increase. The group of fish/ meat/ egg/ milk was categorized as necessities (staple foods) for East Borneo community because its value was not more than 0 . Similarly, it also applied to all area typologies both urban and rural areas. On the one hand, East Borneo is a province whose fish consumption is beyond the national average fish consumption. It is supported by high yields of marine fisheries, public waters and aquaculture. Thus, it was understandable that consuming fish was one of the obligatory menus for households in East Borneo.

\section{CONCLUSION}

According to the above analysis, the researchers drew some conclusions. First, the subsidy revocation for some of 900 VA residential electricity customers and nonsubsidized TTL increase in January 2017 indirectly impact all residential electricity customers other than 900 VA and above customers. Second, the subsidy revocation for some of $900 \mathrm{VA}$ residential electricity customers and non-subsidized TTL increase in January 2017 do not significantly affect 900 VA and above residential electricity customers since they generally capable. Third, based on the types of area, the subsidy revocation for $900 \mathrm{VA}$ customers and non-subsidized TTL increase indicate that the rural households tend to be more responsive than the urban's. This is understandable since the urban electricity customers on electricity dependence is quite high compared to those in rural area. Fourth, the residential electricity customers generally would be more responsive to reduce foods consumption other than staple foods in dealing with the subsidy revocation or TTL increase compared to 900 VA or above customers. It is surely related to the economic condition of the $900 \mathrm{VA}$ residential electricity customers that is more capable and no longer prioritize foods needs as their basic needs. Meanwhile, the middle class economy households would continue to maintain the nutritional status by consuming foods with high level of protein (fish/ meat/ egg/ milk), although they need to reduce other foods consumption. Fifth, the impact of the subsidy revocation policies and TTL increase for 900 VA or above residential electricity customers do not significantly influence the households' behavior in allocating income for food consumption. Sixth, the impact of the subsidy revocation policies for some 900 VA electricity customers and non-subsidized TTL increase for $900 \mathrm{VA}$ or above customers do not influence the level of food and electricity consumption of the capable households.

By referring to the findings, and conclusion, there are some suggestions given by the researchers; the large number of public complaints against government policies in cutting electricity subsidies for 900 VA customers has implied that the revocation and provision of electricity subsidies are supposed to be done as selectively as possible so that it is right on target, so it would reduce inclusive error and exclusive error. One way to do so is by renewing the community data that has the right to obtain the government subsidies. This is in line with 
Malawat's study (2016) that increase in electricity tariffs should pay attention to conditions/ location of area, and income per capita of the community.

In this study the weaknesses of the analysis are described as follows: the impact before and after TTL adjustment policies was assumed that other prices would not change (cateris paribus). In fact, other commodities prices experienced changes. Besides, the observation units before and after the policies used cross section data. It was supposed to be more appropriate when it used panel data observation. It means that the households involved as the observation units in 2016 should be the same as what was used in 2017 , so the changes on the same subjects would be visible.

\section{REFERENCES}

Akili, R. H. (2014). Analysis of Community Income After Electricity Tariff Increase in Kwandang District, North Gorontalo District, 2 (1), 6173. Retrieved from http://unigo.ac.id/jurna 1_akademik/didownload/64/Rustam_HS_A kili_-_Analisis_Pendapatan_Masyarakat_Afte Analysis_Entertainment_Community After_The_Increase_Increase_Disciences_In_ Kec_Kwandang_Kab_Gorut.pdf

BPS of East Kalimantan. (2017a). Socio-Economic Conditions and Important Indicators of the Province of East Kalimantan. BPS of East Kalimantan.

BPS of East Kalimantan. (2017b). Expenditures for Consumption of Indonesian Population by Province.

BPS of East Kalimantan. (2018a). East Kalimantan Province in Figures. BPS of East Kalimantan.

BPS of East Kalimantan. (2018b). Statistics of the Province of East Kalimantan 2018. https://doi.org/Article

Deaton, A. \& J. M. (1980). The Far Ideal Request System. The American Economic Review, 70 (03), 312-326.

Isdinarmiati, T. (2011). Increase in Basic Electricity Tariffs and Policy Responses to Minimize the Negative Impacts on the Indonesian Economy. Bogor Institute of Agriculture (IPB) Postgraduate School.

Kahar, M. (2010). Analysis of Rural and Rural Area Consumption Patterns and Skills with Socio-
Economic Characteristics in Banten Province. Bogor Agricultural Institute.

Ministry of Energy and Mineral Resources. (2017). Electricity Subsidy Policy Targeting Household Power 900 Va.

Komaidi, \& Rakhmanto, P. A. (2010). Measuring the Economic Impact of the 2010 TDL Increase. Obtained from http://www.reforminer.com /wp-content/ uploads/2016/08/ConferencePers-Increase-TDL-2010.pdf

Malawat, M. S. \& M. U. M. P. (2016). The study of the government's electricity cost policy for electricity consumers in terms of the level of the community budget in the district of asahan. Journal of Microeconomic Welfare Economics, 6, 141-148.

Mulyani, D. \& D., \& Hartono. (2018). Effect of Electricity Energy Efficiency in Industrial and Commercial Sectors on Electricity Demand in Indonesia, 11 (1), 1-7. https://doi.org/https: //doi.org/10.24843/JEKT.2018.v11.i01.p01

Rahmi, D. (2001). Analysis of Food Demand and the Impact of Changes in Prices on Household Welfare in West Java (Application of an Nearly Ideal System Model). Bogor Agricultural Institute.

Sahara (2003). Impact of Rising Fuel Prices, Electricity Base Tariffs, Telephone Tariffs and Distribution of Compensation Funds to the Macro and Sectoral Economy in Indonesia. Retrieved from https://repository.ipb.ac.id/ bitstream/handle/123456789/7723/2003sah. pdf? subsequentence $=4 \&$ granted $=y$

Sari, N. A. (2016). Analysis of Rural and Rural Area Consumption Patterns and Their Relationship with Socio-Economic Characteristics in East Kalimantan Province. Indonesian Journal of Economics \& Management, 16 (2), 69. Retrieved from http://ejurnal.unikarta. ac.id/index.php/jemi/article/view/347/pdf

Wihara, Y. and N. C. (2003). The Impact of Increasing Electricity Tariffs Against Household Institutions in Indonesia with the Computational General Balance Model. Metris Journal, 14, 121-130. https://doi.org/10.1016/S00406090(95)06515-6 